\title{
THE IMPLEMENTATION OF SPECIAL EDUCATION LEARNING PROGRAM IN MATHEMATICS AT SDN ISOLA BANDUNG
}

\author{
Arifin Fajar Satria Utama \\ Special Education Study Program \\ School of Postgraduate, Universitas Pendidikan Indonesia \\ Jl. DR. Setiabudi No 229, Bandung, Indonesia \\ E-mail: Bavinclassicart@gmail.com
}

Published date: 10 August 2018

To cite this article: Utama, A. F. S. (2017). The implementation of special education learning program in Mathematics at SDN Isola Bandung. Asia Pacific Journal of Educators and Education, 32, 107 - 115. https://doi.org/10.21315/apjee2017.32.8

To link to this article: https://doi.org/10.21315/apjee2017.32.8

\begin{abstract}
Learning is a process of students' interaction with educators and learning resources in a learning environment. Learning is an assistance provided by educators to stimulate the process of knowledge acquisition, mastering skills and having a good character as well as establishing students' behaviours and beliefs. In other words, learning is a process of helping students to learn well. There are diverse of learning abilities that students have across various classrooms. There are students who have a stronger learning competency better in some subjects than their friends and some are low achievers. Moreover, there are students who are interested in only on one single subject and become high achievers in that lesson. Unfortunately, there are still many schools that generalised learning in the classroom, disregarding students' abilities and intelligence. The preliminary study showed that some students in grade 1 at SDN Isola Bandung had difficulties in learning mathematics. Therefore, a learning program was created to accommodate the students' needs. Thus, the researcher was interested in examining the students' issues in solving math problems and designing individual learning programs for students who had difficulties at SDN Isola Bandung. The researcher used a qualitative case study approach in this research. This learning program was used to obtain information about the learners' problems. The researcher used open interviews and assessments to get the data. Based on this research, the result shows that the students in grade 1 at SDN Isola was able to do the math problems correctly by using the modified learning program.
\end{abstract}

Keywords: Learning, learning program, mathematics, learning program modification 


\section{INTRODUCTION}

In Indonesia, teaching holds in one activity is known as teaching terms, which is mechanical and poses the teacher as an authority for teaching, so the teacher can be the centre of activities. Teaching can be seen as a system consisting of components that are dependent on one another and organised across competencies that students have to be reached by students, subject matter of learning, main discussion, method and teaching approach, teaching media, learning resources, class organisations and assesment or evaluation. There are many components in teaching that can be classified in some activity, including assesment, planning, process and evaluation.

A good teacher will try as best as possible so that the teaching can be successful. One way of doing so is making a teaching plan prior to lessons. According to Hamalik (2001, p. 135) planning can also help with:

1. Giving the teacher a further undertanding about the purpose of school education and the relationship with teaching implemented to achieve that goal;

2. Assisting the teacher in clarifying thoughts about teaching contributions towards the achievement of educational objectives;

3. Adding to the teacher's belief on the value of teaching given and the procedures used;

4. Helping the teacher learn the needs of students, interests of students and encourage motivation to learn;

5. Reducing activities that are "trial and error" in teaching with the organisation of the curriculum, thereby saving time;

6. Students will respect teachers who carefully prepare to teach according to their expectations;

7. Providing opportunity for the teachers to advance their personal nad professional development.

8. Helping teachers to believe in themselves;

9. Helping teachers maintain enthusiasm to teach and always deliver the upto-date materials.

The process of teaching and learning is at the core of educational activities in school. In teaching, the teacher experiences the role as a leader and is responsible for that leadership. According to Suryo (2009, p. 16), the process of teaching and learning includes activities done by the teacher starting with planning, and 
implementing activities through evaluation and follow-up programs that takes place in educational situations to achieve certain goals, namely teaching. Teachers who are competent will be able to create effective learning environments and will be able to manage the learning process, so that student learning outcomes are at an optimal level (Uzer Usman in Suryo, 2009, p. 17).

According to Percival (in Hamalik, 2001, p. 146), "the evaluation.....as a series of activities that are designed to measure the effectiveness of a teaching/learning system as a whole (the evaluation is a series of activities designed to measure the effectiveness of the system of teaching/learning as a whole)". Meanwhile, Norman E. Gronlund (in Purwanto, 2004, p. 3) says that "evaluation is a systematic process of determining the extent to which instructional objectives are achieved by pupils", meaning that evaluation is a systematic process to determine or make a decision regarding the extent to which the goals of teaching have been achieved by the students. The evaluation was intended to observe the students' learning outcomes and attempt to determine how to create learning opportunities. In addition, the evaluation also related to the observation of the role of the teacher, teaching strategies, special curriculum materials, and principles of learning to be applied in teaching. Some of the terms, such as assessment and measurement, are related to the evaluation. The assessment was associated with a series of activities designed to measure student achievement through an instructional program. In addition to assessing students, assessments also assess the teaching system. As for the measurements, descriptive data was collected about the students' products and/or the behaviour of the students, and was associated with the achievement standards or norms.

\section{METHODOLOGY}

Based on the issues raised, this research used a qualitative approach, with the design of a case study research. The data presented is a narrative or a description of the analysis concerning problems in the learning process as perceived by learners in SDN Isola, as well as how the problem arose, namely how learning was modified and modifications' impact on the students at SDN Isola. The study observed first grade students in SDN Isola. Previous researchers have conducted preliminary studies to determine what problems were perceived by learners and teachers then facilitated the needs of learners.

Data collection was done by testing the process of learning using the design of learning programs in sync according to the needs of the participants. Then, openended interviews with students and teachers were conducted. The interviews were 
not structured, so researchers could accept as much information as possible from the subject of the research. But the presence of the interview guide remained focused on the problems experienced by learners and teachers. The researchers also conducted observations three times to find out how the process of teaching and learning before and after using the modifications to support the learning.

\section{DISCUSSION}

In carrying out the program, beginning with the results, then analysing the curriculum, we created a syllabus and planned the implimentation of the learning course, paying attention to environmental factors such as classroom conditions, availability of media, and so on.

We first provided the modelling prior to the learning activities, which, according to our analysis and the teacher, was still lacking to accommodate all the needs of the learners. Without patronising, we tried to evaluate classroom learning through the class teacher. We first evaluated classroom management in a sitting position. We set up seats with four rows randomly set that had learners who were categorised as independent, instruction and frustration. Figure 1 shows the set up of the seated position.
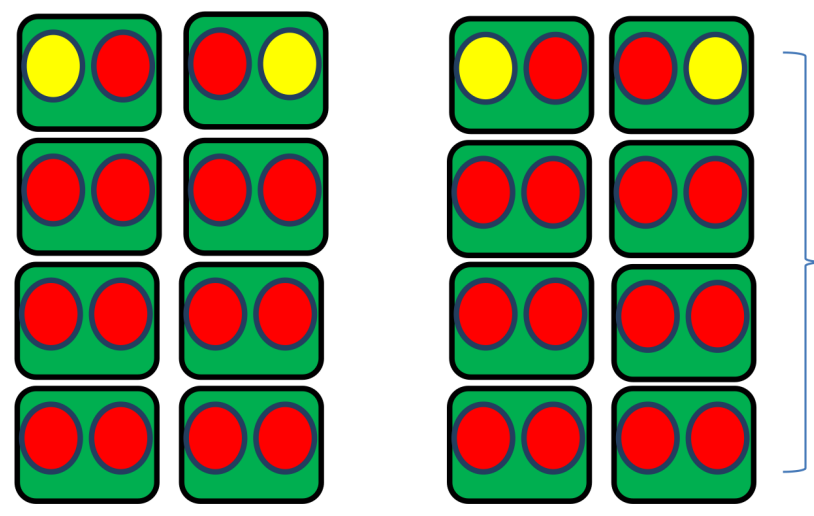

Consists of Independent, instruction, and frustation

Figure 1. Set up of the seated position

The seating arrangement was intended toe help of peers. Students who belonged to the frustration level were not together in one table either in the front or in the back of the class. Additionally, teachers were also expected to classify the students but there were students who were included in the independent level, instruction level and frustration level. This was done sto promote peer tutoring. After the seating 
arrangements and the composition of the learners was completed, the next step was "ice breaking". Ice breaking stimulates concentration and self-confidence of learners. We only used provided modelling of how to accommodate students in particular. Akhsan has, Hafidz and Raia are the subjects in the Thematic lesson plan. We use the Thematic learning programs because it covers mathematics. Students were given materials about the patterns of numbers. We explained how to do summation of the number two.

\section{Example:}

$$
\begin{aligned}
& 2+2=4 \\
& 4+2=6 \\
& 6+2=8 \\
& 8+2=10 \\
& 10+2=12 \\
& 12+2=14
\end{aligned}
$$

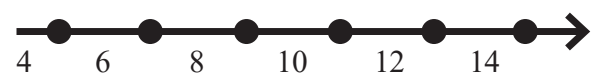

Or

$$
\begin{aligned}
& 1+3=4 \\
& 4+3=7 \\
& 7+3=10 \\
& 10+3=13 \\
& 13+3=16
\end{aligned}
$$

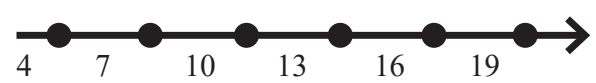

- To Akhsan has, 14 consists of a ten. which explains the ten and four in the unit with the description as above

- To Raia, the teacher explains that the + summation moves forward to right the as above and the reduction moves backward to the left like the following.

$7-2=5$

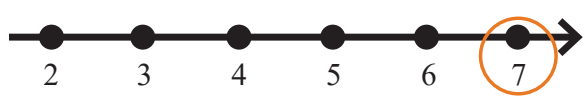




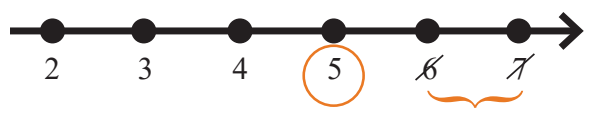

In the subtract $(-) 2$

Or it can be exemplified using concrete objects.

After the material was given, students were given tasks in the form of questions such as the following :

\section{For all students except Raia and Akhsan has}

Fill in the dots below

1. Draw the stars to form a number pattern
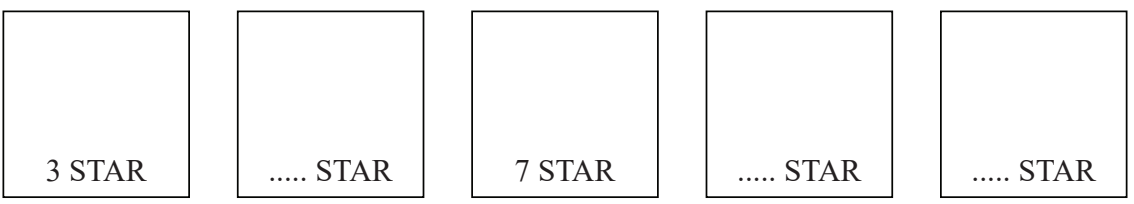

2. The numbers that are located between 32 and 34 is ...

3. The number that lies between 30 and 32 is ...

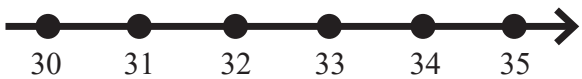

4. Complete the number line below.

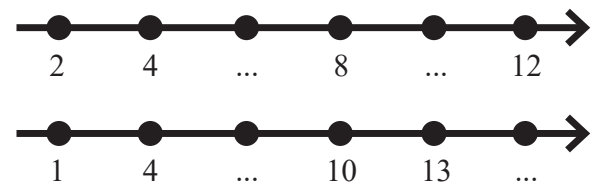

\section{For Akhsan has}

Fill in the dots below.

1. 1 tens +8 units $=\ldots$

2. 3 tens +2 units $=\ldots$

3. $14=\ldots$ tens $+\ldots$.unit

4. $35=\ldots$ tens $+\ldots$ unit 


\section{For Raia}

Fill in the dots below.

1. There are many stars in the sky at night. Count how many stars in the box below.

Di malam yang cerah, banyak bintang terlihat.

Hitunglah banyak bintang di bawah ini.

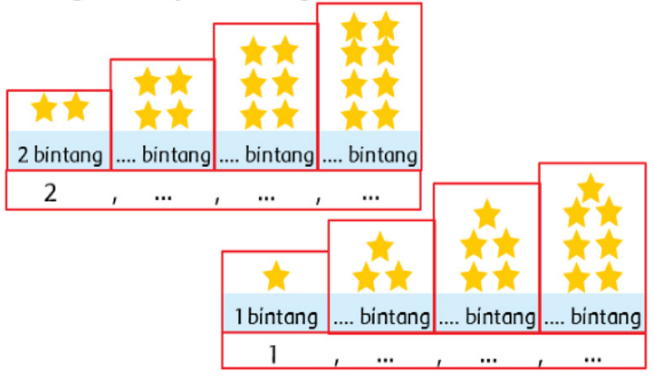

2.

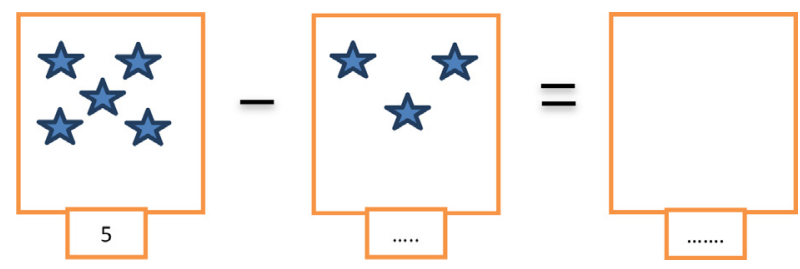

3. $7-4=\ldots$.

4. $9-6=\ldots \ldots$

After giving these questions, we discussed with the homeroom teacher about the program that was to be implemented independently by the class teacher. The teacher could carry out the Individual learning programs plan (Akhsan has, Hafidz and Raia) into the classic learning programs in the form of thematic. For example, the teacher could use the Individual lesson programs on enrichment hour (except Thursday, Friday or Saturday, which are the curriculum days), The teacher already understood how to accommodate all the needs of the learners in grade 1 without pulling out learners who experienced barriers to learning mathematics.

In the future, the teacher will re-run the program that were created together between the team accommodating the needs of all learners in the class. Of course this need support and ongoing evaluation so that the learning process can be a reciprocal relationship that leads to change for the better. 
Table 1. Differences in teacher's competence

\begin{tabular}{lll}
\hline Aspects & Before & The implementation \\
\hline Learning Methods & $\begin{array}{l}\text { Using only the lecture method, with } \\
\text { a lesson programs plan or syllabus, } \\
\text { using scientific approach. }\end{array}$ & $\begin{array}{l}\text { The teacher not only gives lectures, } \\
\text { but also provides a stimulus to make } \\
\text { students active. }\end{array}$ \\
Learning Media & Uses the media potluck & $\begin{array}{l}\text { The use of media is varied and makes } \\
\text { children happy. }\end{array}$ \\
$\begin{array}{l}\text { Classroom } \\
\text { management }\end{array}$ & $\begin{array}{l}\text { The teacher provides the material } \\
\text { in the classical, remedial and } \\
\text { enrichment of the given lesson. }\end{array}$ & $\begin{array}{l}\text { The teacher would go to learners } \\
\text { who experience difficulties especially } \\
\text { the subject group. Teachers are also } \\
\text { willing to share time outside of class } \\
\text { hours to provide remedial classes for } \\
\text { those who fall behind in lessons. }\end{array}$ \\
\hline
\end{tabular}

\section{CONCLUSION AND SUGGESTIONS}

Observation with regard to the activities of the learning was done in SDN Isola Bandung with 40 students. Based on the results, there were four students who had barriers in mathematics. All students in the classroom required a learning program that was able to accommodate all the needs of the students, including students who excelled and students whose achievements was lower than other students.

Learning activities should emphasise assistance and tutoring to each individual. All students in the class should be viewed as having uniqueness and different learning needs. This can be met if teachers create individualised programs based on the advantages, disadvantages and learning needs of each student. Individual learning focuses on the needs of the students and is the result of analysing the assessment process. .

In addition to individual programs, class management should be balanced with the use of models, methods, media, resources, and the learning process are varied so as to accomodate for the diversity of the students in the class and meet their needs.

Based on the conclusion above, the researcher felt that there should be support to continue developing modifications to learning strategies in facilitating students so they can learn optimally and to achieve educational goals. 


\section{REFERENCES}

Alimin, Z. \& Rochyadi, E. (2003). The development of the program of learning of individual children with mental retardation. Jakarta: Directorate Of Higher Education Ministry Of National Education.

Alimin, Z. (2010). Learning difficulties in the perspective of education. [Online]. Available at: http://z-alimin.blogspot.com.

Arends, R. (1997). Classroom instructional and management. New York: McGraw Hill Comapanies.

Mulyasa, E. (2010). Education unit level curriculum (KTSP). Bandung: Remaja Rosdakarya.

Hamalik, O. (2001). The teaching and learning process. Jakarta : Earth Literacy.

Ibrahim, M. (2000). Cooperative learning. Surabaya: University Press.

Piaget, J. (1965). The moral judgment of the child. New York: The Free Press.

Purwanto, N. (2002). The principles and techniques of evaluation of teaching. Bandung: Remaja Rosdakarya.

Purwanto, N. (2004). The psychology of education. Bandung: Remaja Rosdakarya.

Slavin, E. R. (2005). Cooperative learning: Theory, research and practice. Bandung: Nusa Media. https://doi.org/10.4135/9781412952484.n158

Sundari. (2011). The grandchildren: Observation and interviews. In The handout: Courses of study special needs. Bandung: The department of Education UPI.

Suryo, S. (2009). The process of teaching and learning in schools. Jakarta: Rineka Cipta.

Law Number 20 Year 2003 On National Education System Article 36.

Warsono \& Hariyanto. (2012). Active learning. Bandung: Remaja Rosdakarya. 